\author{
Jan Olszanowski, Wojciech Piątek
}

\title{
The validity of the principle of mutual trust between the EU Member States in mutual assistance for the recovery of public claims ${ }^{1}$
}

\section{Introduction}

The flow of capital among states and continents, including the migration of people that increases each year, has entailed that states must establish legal regulations that prevent fraud and budget losses. Europe witnessed such actions as early as the Interwar Period, primarily consisting in establishing legal mechanisms aimed at avoiding double taxation $^{2}$. The first normative act adopted by the present European Union that directly governed mutual assistance of the Member States for the recovery of public claims was the Council Directive 76/308/EEC of 15 March 1976 - on mutual assistance for the recovery of claims resulting from operations forming part of the system of financing the European Agricultural Guidance and Guarantee Fund, and of agricultural levies and customs duties $^{3}$. This act was implemented as a consequence of the failure to enforce the claim for recovering public claims that emerged prior to its enactment.

From 1976 until now, cooperation between the EU Member States has been gradually strengthened through expanding the subjective scope to new categories of public claims, establishing three separate cooperation forms, most notably the possibility to recover claims arising in one state by authorities of another state, and establishing separate in-

1 This article was written on the basis of the project financed by the National Science Centre under the decision of the Director of the National Science Centre dated 13 October 2011, decision no. DEC-2011/01/D/HS5/01526.

2 V. more. F. Cannes, The Historical Development of the Exchange of Information for Tax Purposes, [in] Exchange of Information for Tax Purposes, ed. O.Ch. Günther, N. Tüchler, Wien 2013, pp. 18-22.

3 Council Directive 76/308/EEC of 15 March 1976 on mutual assistance for the recovery of claims resulting from operations forming part of the system of financing the European Agricultural Guidance and Guarantee Fund, and of agricultural levies and customs duties (Official Journal of the European Union No 333 of 24 December 1977), hereinafter referred to as Directive 76/308/EEC. 
stitutional frameworks of cooperation. ${ }^{4}$ In the current legal status, the basic EU legal acts are the Council Directive No 2010/24/EU of 16 March 2010 concerning mutual assistance for the recovery of claims relating to taxes, duties and other measures, ${ }^{5}$ and the Commission Implementing Regulation (EU) No 1189/2011 of 18 November 2011, which lays down detailed rules in relation to certain provisions of Council Directive 2010/24/ EU concerning mutual assistance for the recovery of claims relating to taxes, duties and other measures. ${ }^{6}$

The aforementioned EU legal acts have already been analysed by researchers from many European countries. ${ }^{7}$ Council Directive 2010/24/EU was implemented into the laws of all the EU Member States. In practice, mutual assistance between the EU Member States for the recovery of claims relating to taxes, duties and other measures covers millions of euros. In 2011 the total amount of the recovered amounts amounted to $€ 62,475,879$. In 2012 this amount significantly declined to $€ 32,076,738$. However, 2013 witnessed the growth to $€ 41,115,223$. $^{8}$

The aim of this study is to analyse the current international cooperation in the recovery of public claims in view of the principle of mutual trust between the Member States, which forms the basis for such cooperation. The characteristic feature of mutual assistance for the recovery of public claims is to assist the other Member State without acquiring any mutual benefits automatically and being sure that the assisted Member State will be equally committed to executing the request for assistance received from another Member State. In the light of the foregoing, it is necessary to analyse the provisions of Directive No 2010/24/EU and of Regulation No 1189/2011 with respect to the building of mutual trust between the Member States, i.e. which provisions are appropriate for implementing this principle and which provisions are contrary to it. The principle of trust is also manifested in practical terms, i.e. the actual financial effects of assistance provided by the Member States. It will be discussed separately on the basis of figures provided by the central liaison offices in the Czech Republic, Latvia, Poland, Portugal, Slovakia and

4 V. more: J. Olszanowski, W. Piątek, The development of mutual assistance of EU Member States for the recovery of public claims, "Law Review" 2014, vol. 2, pp. 68-69.

5 OJ EU L 84 of 31 March 2010

6 OJ EU L 2011.302.16 of 19 November 2011.

7 R. Seer, Die Vollstreckungsamtshilfe in Steuersachen nach der neu gefassten Beitreibungsrichtlinie 2010/24/EU, „IWB” 2011, vol. pp. 145-152, I. Gabert, Deutsche Beitreibungsamtshilfe nach dem EU-Beitreibungsgesetz (EU-BeitrG): Úberblick und Bezüge zum Ertragsteuerrecht, "FinanzRundschau" 2012, vol. 15, pp. 707-715, B. Ludwig, Das neue EU-Vollstreckungsamtshilfegesetz, „SWI” 2012, vol. 7, pp. 323-328, M. Kortz, Grenzüberschreitende Vollstreckung von Steuerforderungen im EU-Raum nach dem EU-Beitreibungsgesetz vom 7.12.2011, "Der Betrieb" 2012, vol. 43, pp. 2422-2427; J. Olszanowski, W. Piątek, The development of mutual assistance of EU Member States for the recovery of public claims, "Law Review" 2014, vol. 2, pp. 69-76.

8 V. more: EU and International Tax Collection News 2014, vol. 1, p. 4. 
Sweden. Those states provided the authors of this study with detailed responses to questions about the practical aspects of mutual assistance for the recovery of public claims.

\section{Content and significance of the principle of trust}

The principle of trust is not directly specified in the provisions of Directive 2010/24/EU and of Regulation No. 1189/2011. This principle, however, results from the entire legal regulations governing mutual assistance for the recovery of claims relating to taxes, duties and other measures. The truth is that the Member State applying for assistance, except for making the request for such assistance, is not authorized to force the authorities of the requested Member State to apply specific legal measures necessary to perform the request or counteract the inactivity with respect to its performance. ${ }^{9}$ However, the basis for efficiency and effectiveness of mutual assistance for the recovery of tax claims should be the existence of trust between individual Member States, according to which the officials of relevant authorities of each Member State make as much effort as possible to assist the authorities of another Member State and obtain such assistance.

This principle is indirectly expressed in the assumptions of the preamble to Directive 2010/24/EU, and it needs to be achieved through performing its provisions. Striving for better security of the financial interests of the Member States, and for the neutrality of the internal market, including the growth in efficiency and effectiveness of assistance, cannot be achieved without the principle of trust. If a specific member State desired to reap the benefits of cooperation without being ready to assist other member States, then such assistance would be of a unidirectional nature. There would not be any opportunity to equally secure the financial interests of all the Member States and this would be contrary to the principle of equal treatment of domestic and foreign claims by the Member State specified in Article 13(1) of Directive 2010/24/EU.

The principle of trust, which forms the basis for the existence and operation of the European Union with respect to mutual assistance for the recovery of public claims, provides that the relevant tax officials of each Member State that cooperate as part of mutual assistance for the recovery of public claims take such actions based on the implemented $\mathrm{EU}$ and domestic laws that lead to the most efficient and effective response to the request of another Member State.

The validity of such principle is a sine qua non condition of the implementation of the goals that constitute the basis for mutual assistance between the Member States for the recovery of the public claims. The trust between the Member States, most notably between the officials appointed to perform requests for assistance is built not on the

9 Therefore, some representatives of the doctrine claim that one of the principles of mutual assistance is the passive effect of the authorities of the applicant Member State on the authorities of the requested Member State. V. R. Seer, op. cit., p. 149. 
basis of the general assumptions and ideas governing the existence of the European Union, but rather on the basis of the mutual involvement in actions taken by the Member States, aimed at protecting financial interests. The absence of mutual trust, or a low level of trust, should provoke questions about the sense of such mutual assistance, the need to maintain in each Member State the qualified officials of public administration responsible for such assistance, and the activity of the EU legislature.

Despite the crucial role of the principle of trust in terms of the efficiency and effectiveness of mutual assistance, it is hard to simply determine how much it effectively applies in individual Member States, or to what extent it has been replaced with a lack of trust in the success of mutual assistance for the recovery of public claims. The validity of the principle of trust may be analysed from a twofold point of view. The formal point of view analyses the legal regulation that forms the basis for assistance. From the material point of view, the existence of the principle of trust may be reviewed in terms of the effectiveness of mutual assistance between the Member States. Those issues will be discussed in the two subsequent chapters of this study.

\section{Normative approach of the principle of trust}

\section{The regulations favourable to establishing the principle of trust}

The analysis of Directive 2010/24/EU gives rise to the formulation of the principle of full trust between the EU Member States. Such a conclusion seems to be natural, since the mechanisms of mutual confidence between the EU Member States were established in such a way that they contribute to the maintenance of full trust. Among all the provisions of the EU law in this field, special attention needs to be focused on the following regulations.

Firstly, the building of trust is fostered by the exchange of information between the EU Member States without prior request. This is set forth in Article 6 of Directive 2010/24/EU. On the one hand, the spontaneous exchange of information means that there is no obligation to provide such information, but on the other hand the Member State may voluntarily inform the relevant authority of the other Member State about events that may require its financial interests to be protected. The basic advantage of this cooperation between the Member States is the possibility to provide a specific Member State with some unexpected and valuable information. Further, the receiving Member State does not need to make any efforts to this extent. ${ }^{10}$ Each Member State that provides information in this way probably hopes that such information will also be submitted to them in the event that tax is returned to the entity seated or residing in such a Member State.

10 Y. Jeong, Spontaneous exchange of information, [in] Exchange of Information..., op. cit., p. 459. 
Secondly, trust may grow thanks to the presence of officials of the applicant Member State in administrative authorities and their participation in administrative proceedings. Pursuant to Article 7 of Directive 2010/24/EU, officials authorised by the applicant authority may - in order to support mutual assistance - be present in the offices where the administrative authorities of the requested Member State carry out their duties, while administrative enquiries are carried out in the territory of the requested Member State; and they may assist the competent officials of the Member State during court proceedings in that Member State. Article 7(2) of Directive 2010/24/EU provides for further forms of cooperation, such as the possibility to interview individuals and examine records made by officials of the applicant Member State, in so far as it is permitted under the legislation in force in the requested Member State. In the reference books about this form of cooperation it was noticed that its main disadvantage is the lack of influence of the officials of the applicant authority on the enforcement measures conducted by the officials of the requested authority. ${ }^{11}$ The lack of explicit regulation on this matter should not, however, overshadow the positive aspects arising from the mutual actions taken by the officials of two Member States in order to perform a specific public obligation. ${ }^{12}$ Thanks to their visit to the authority of the requested Member State, the officials of the applicant Member State have greater access to information and the method of taking enforcement actions by the officials of the requested Member State. ${ }^{13}$ The use of this form of cooperation by the Member State may affect the building of trust between the officials in non-legal areas. The opportunity for common meetings and work, and mutual observation of the officials' working methods, may contribute to increasing or undermining the mutual trust.

Thirdly, a major novelty in mutual assistance implemented in Article 12(1) of Directive 2010/24/EU is the uniform instrument permitting enforcement in the requested Member State without any act of recognition, supplementing or replacement in that Member State. Directive 2010/24/EU is novel in comparison with the heretofore legal frames of mutual assistance. This uniform instrument permits enforcement in legal transactions and demonstrates the validity of the principle of trust. The regulation ensures that the uniform instrument permitting enforcement issued in one Member State constitutes the exclusive basis for enforcement actions in any other EU Member States.

Fourthly, considering the validity of the principle of trust, a positive role is played by the Member States' renunciation of all claims on each other for the reimbursement of costs arising from any mutual assistance as set forth in Article 20(2) of Directive

11 I. Gabert, Deutsche Beitreibungsamtshilfe nach dem EU-Beitreibungsgesetz (EU-Beitr G): Überblick und Bezüge zum Ertragsteuerrecht, "Finanz-Rundschau" 2012, vol. 15, pp. 712-713.

12 R. Seer, op. cit., p. 150.

13 J. Lao, The Council Directive concerning Mutual Assistance for the Recovery of Claims, [in] Exchange of Information..., op. cit., p. 314. 
2010/24/EU. This rule is not contrary to its exceptions set forth in Article 20(2)-(3) of Directive 2010/24/EU, which are of a specific nature. Formally, the principle of trust operated to such an extent that the Member States decided in advance to renounce all claims for the reimbursement of costs arising from any mutual assistance, irrespective of their amounts or sources.

Fifthly, mutual trust is inspired by the obligations of the applicant Member State and the requested Member State to forthwith inform each other about any and all events that are crucial in terms of the execution of the request for assistance. This obligation is specified in the individual provisions of Directive 2010/24/EU and of Regulation No 1189/2011. The requested authority is obliged to inform the applicant authority of the grounds for refusing a request for information [Article 5(4) of Directive 2010/24/ EU], a request for notification [Article 8(3) of Directive 2010/24/EU], or a request for recovery of claims [Article 13(2) of Directive 2010/24/EU]. The duty of mutual information is essential in the case of disputes concerning the enforced claim [Article 14(2) and (4) of Directive 2010/24/EU], any amendment to its request for recovery or of the withdrawal of its request [Article 15(1) of Directive 2010/24/EU], or any actions that interrupt, suspend or prolong the limitation period of the claim [Article 19(3) of Directive 2010/24/EU]. On the other hand, Regulation No 1189/2011 frequently provides that the requested authority must acknowledge as soon as possible the receipt of the request for information [Article 7 of Regulation No 1189/2011], the request for notification [Article 12(1) of Regulation No 1189/2011], or the request for recovery or for precautionary measures [Article 19(1) of Regulation No 1189/2011].

\section{Regulations undermining the principle of trust}

Although the provisions of Directive 2010/24/EU and of Regulation 1189/2011 aim at effective mutual assistance between the Member States for the recovery of claims relating to taxes, duties or other measures, and thus establishing the principle of trust, those provisions also include some provisions that may undermine mutual trust. They include mechanisms that allow the Member State to renounce the request for assistance made by the authority of the applicant Member State, and negative reasons that curb the obligation to cooperate, associated with the limitation period and the claim amount.

Limits to the requested authority's obligations to grant mutual assistance are set forth in Article 18 of Directive 2010/24/EU. Except for some vague premises, such as serious economic or social difficulties in the requested Member State as a result of the performance of the request for recovery, this provision includes two specific premises concerning the refusal to cooperate. The first one is the expiry of the 5 year period from the deadline for claim payment in the applicant Member State to the date of making the first request for assistance. According to the second premise, the claim amount should be for a minimum of $€ 1,500$. 
By focusing only on those two reasons, despite the fact that their occurrence does not automatically give rise to assistance but only grants such a right to another Member State, the existence of those premises may undermine the trust between the Member States, and consequently reduce the efficiency of mutual assistance. On the one hand, bearing in mind the fact that the limits of amounts and of time limits for the granted assistance ${ }^{14}$ were implemented on purpose, it would completely develop, if any barriers to this extent were eliminated and, at the same time, attention was drawn to the elimination of such legal regulations and practices that make mutual assistance for the recovery of public claims ineffective.

\section{Practical approach of the principle of trust}

When not considered in its formal form, the principle of trust is primarily and essentially of a practical nature, which may be indirectly seen from figures concerning the number of requests made by individual EU Member States for assistance in each of its existing forms, and from the actual financial benefits acquired by the states from their claimed debts. First of all, it is noteworthy that the available data do not give rise to the formulation of this thesis concerning the complete and unobstructed principle of trust between the EU Member States in mutual assistance for the recovery of public claims.

As for Poland's experience in the analysed period, in 2013 Poland provided other states with 290 requests for information, 106 requests for notification and 65 requests for claims at the aggregate amount of $€ 26,341,545.18$ and in total received from all the EU Member States 891 requests for information, 595 requests for notification and 1445 requests for claims at the aggregate amount of $€ 98,855,236.31$. In the first 10 months of 2014 the activity of the Polish administrative authorities considerably increased as they sent other Member States 917 requests for information (received only 579 requests), 98 requests for notification (received 295 requests) and 332 requests for recovery of claims totalling $€ 1,966,668.20$, and received from other Member States 2377 requests amounting in total to $€ 63,417,990.34 .{ }^{15}$ Both the number of requests and amounts of the recovered claims prove the significance of and the need for the cooperation between the Member States with respect to the recovery of public claims. However, the Polish Central Liaison Office has not disclosed any information on the amounts of the effectively recovered claims requested by other EU Member States in 2013 and 2014.

In 2013 the Czech Republic made 24 requests for information, 6 requests for notification and 113 requests for recovery, and received 102 requests for information, 47 requests for notification and 113 requests for recovery. In 2014 this Member State made 37 re-

14 V. more: J. Lao, op. cit., pp. 321-322.

15 Letter of the Head of the Tax Chamber in Poznan dated 16 December 2014, No KO/0610042/14/BIP (executed in response to the authors' request). 
quests for information and received 121 requests of the same from other Member States, made 112 requests for recovery (and received 170 requests), and it did not make any requests for notification (but received 26 requests from other Member States). Further, in 2014 the Czech Republic made requests for recovery of claims totalling $€ 1$ 150,013,661, whereas the received requests amounted in total to $€ 324,727.90$ (in 2013 this amount was $€ 86,714.97$, whereas the received requests amounted to $€ 198,020.98) .{ }^{16}$ Just like the Polish Central Liaison Office, the Czech office did not provide any data showing the actual amounts of the recovered claims.

In 2014 Slovakia made 11 requests for information (with 52 requests of the same kind in 2013), 10 requests for notification (4 requests in 2013) and 63 requests for recovery (100 requests for recovery in the previous year). On the other hand, this country received 206 requests for information (131 in 2013), 30 requests for notification (28 in 2013) and 207 requests for the recovery of claims. In 2014 the requests for the recovery of claims amounted to $€ 1,100,249.00$ ( $€ 848,012.00$ in 2013). ${ }^{17}$ As is the case for Poland and the Czech Republic, no specific data on amounts of the recovered claims for individual years were provided.

The data obtained from Sweden only apply to the number of requests sent to other Member States in general. In 2014 this State made 576 requests for assistance in comparison with 547 requests in 2013. ${ }^{18}$ As for the data received from Sweden, in 2014 this state requested the recovery of $€ 27,926,625.00$ ( $€ 107,363,538.00$ in 2013). The amount of $€ 1,438,626.00$ ( $€ 913,620.00$ in 2013) was recovered. In 2014 this state received a total of 134 requests, compared to 116 requests in 2013. The comparison of amounts requested by Sweden with the amounts recovered for other EU Member States shows a low percentage of the recovered amounts, which equalled 0.85\% in 2013 and 5.15\% in 2014.

In 2014 the Republic of Latvia made a total of 32 requests for assistance in comparison with 63 requests in 2013. The requests for the recovery of claims concerned the amount of $€ 9,607,972$.64, of which $€ 49,562.77$, or $0.34 \%$, were recovered ( $€ 3,644,664$. 82 in 2013 , of which $€ 12,572.43$, or $0.51 \%$, were recovered). The Republic of Latvia received 108 requests in total in 2014, compared to 67 requests in 2013. ${ }^{19}$

The interesting example of the effectiveness of recovery of claims is data obtained from Portugal. In 2014124 requests at the aggregate amount of $€$ 17,899,616.00 were made and the amount of $€$ 2,186,394.00, or 12\%, was recovered (in 2013154 requests

16 The letter of the Ministry of Finance of the Czech Republic dated 15 May 2015 (made with response to the authors' request).

17 The letter of the Financial Directorate of the Slovak Republic, Section for Tax Offices dated 22 May 2015, No 1070002/1/191647/2015 (executed with response to the authors' request).

18 The letter of the Swedish Enforcement Authority dated 10 March 2015, ID:15MBKFM59838 (executed in response to the authors' request).

19 The letter of the State Revenue Service of Latvia, Tax Debt Enforcement Department dated 15 April 2015, No 4.3-13/52 (executed in response to the authors' request). 
totalled $€ 134,487,630.00$ and $€ 1,107,540.00$, or $0.82 \%$, were recovered). Portugal obtained 192 requests for information (165 requests in 2013, 15 requests for notification (12 requests in 2013). ${ }^{20}$

As for the parties collaborating in this kind of cooperation, such cooperation fundamentally applies to neighbouring states. For example, the Czech Republic most frequently received requests from Slovakia, Germany and Austria. ${ }^{21}$ Poland obtains the largest number of requests from Germany. ${ }^{22}$

The exchange of information by the Member States without a previous request (spontaneous exchange of information) is not a common occurrence. The data acquired by the authors prove that Sweden receives information as part of the so-called spontaneous exchange but it does not submit to other Member States any information about the possible recovery of taxes, duties or other measures, even if it is aware of the same. The requests for information generally apply to addresses and data on debtor's assets. ${ }^{23} \mathrm{Ac}-$ cording to the Minister of Finance of the Czech Republic this state provides information on the expected recovery of taxes exceeding 250,000.00 Czech crowns. ${ }^{24}$ The Portuguese authorities acknowledged that the spontaneous exchange of information applies to information received from Germany. ${ }^{25}$

According to the data acquired by the authors, so far the EU Member States have not decided to commence the collaboration aimed at the mutual participation of their officials in enforcement activities.

Moreover, the received responses do not show that the principle of mutual renunciation of claims relating to the recovery of costs arises from mutual assistance.

\section{Conclusion}

From the very beginning, the mutual assistance of the EU Member States for the recovery of public claims was based on mutual trust, respect for the financial interesst of each state, and the involvement of officials of all the Member States in achieving the

20 The letter of Ministerio das Financas, Direccao-Geral dos Impostos, Comissao Interministerial em Mateira dated 22 April 2015 (executed in response to the authors' request).

21 The letter of the Ministry of Finance of the Czech Republic dated 15 May 2015 (made with response to the authors' request).

22 Letter of the Head of the Tax Chamber in Poznan dated 16 December 2014, No KO/0610042/14/BIP (executed in response to the authors' request).

23 The letter of the Swedish Enforcement Authority dated 10 March 2015, ID:15MBKFM59838 (executed in response to the authors' request).

24 The letter of the Ministry of Finance of the Czech Republic dated 15 May 2015 (made with response to the authors' request).

25 The letter of Ministerio das Financas, Direccao-Geral dos Impostos, Comissao Interministerial em Mateira dated 22 April 2015 (executed in response to the authors' request). 
best possible results of such assistance. The principle of trust is always essential for the efficiency and effectiveness of the granted assistance.

From a formal point of view, in both Directive 2010/24/EU and Regulation 1189/2011 the EU legislature placed great emphasis on the most transparent development of relationships between the EU Member States, and thus the validity of the principle of trust. This is manifested by the regulation pertaining to the so-called spontaneous exchange of information, officials' participation in enforcement measures conducted in another Member State, the uniform instrument permitting enforcement, renunciation of claims concerning costs of mutual assistance, and immediate notification of any and all events that are essential in terms of the execution of the request for assistance. The history hitherto of developing the rules for mutual assistance for the recovery of public claims considerably consists in enhancing the cooperation in the aforesaid fields.

From the practical point of view, it may be noticed, however, that closer international cooperation in the analysed area is not translated into the actual increase in trust and the involvement of officials of individual public administrative authorities. This is reflected by the small amount of the recovered claims and by the practical use of such possibilities as the spontaneous exchange of information, or the involvement of the officials in enforcement measures conducted in another Member State. In general, the Member States unwillingly share information on the practical aspects of the granted assistance, hiding behind the fiscal secret, most notably providing information on the enforced amounts on a resistant basis. The same applies to the European Commission, which does not provide any details in this regard despite having such information, according to Article 27(1) of Directive 2010/24/EU. ${ }^{26}$

Therefore, it is possible to formulate the thesis that it takes a lot of time to achieve the high trust level between the EU Member States, with respect to the recovery of public claims. The constraints on the achievement of this goal are not of a legal nature but of an actual one. It seems that the individual participants of this process would like to gain too much for themselves in such mutual assistance and do not give too much in return.

Thinking about any further fate of the mutual assistance between the EU Member States for the recovery claims concerning taxes, it should, after all, develop with respect to the closer procedural regulations and social and economic reasons, most notably the constant migration of people in Europe. It seems that considering the increasing technical possibilities with respect to the data exchange, the automatic information exchange procedure will develop. ${ }^{27}$ It is also essential to effectively use the on-going mutual assistance instruments, apply instruments that are only theoretical and overcome problems concerning the low level of assistance effectiveness. This is the only way to develop the

26 The letter of the European Commission dated 10 February 2015, TAXUD R2/SV-ARES(2015) 593275 (executed in response to the authors' request).

27 S. Parida, Automatic Exchange of Information, [in] Exchange of Information..., op. cit., pp. 437-438. 
trust level between the EU Member States, which, besides its legal nature, is also of an actual and social nature and cannot be verified easily. It depends considerably on the mutual effectiveness of the granted assistance.

\section{Literature}

Cannes F., The Historical Development of the Exchange of Information for Tax Purposes, [in] Exchange of Information for Tax Purposes, eds. O.Ch. Günther, N. Tüchler, Wien 2013.

Gabert I., Deutsche Beitreibungsamtshilfe nach dem EU-Beitreibungsgesetz (EU-BeitrG): Úberblick und Bezüge zum Ertragsteuerrecht, "Finanz-Rundschau" 2012, no. 15.

Jeong Y., Spontaneous exchange of information, [in] Exchange of Information for Tax Purposes, eds. O.Ch. Günther, N. Tüchler, Wien 2013.

Kortz M., Grenzüberschreitende Vollstreckung von Steuerforderungen im EU-Raum nach dem EU-Beitreibungsgesetz vom 7.12.2011, "Der Betrieb” 2012, no. 43.

Lao J., The Council Directive concerning Mutual Assistance for the Recovery of Claims, [in] Exchange of Information for Tax Purposes, eds. O.Ch. Günther, N. Tüchler, Wien 2013.

Ludwig B., Das neue EU-Vollstreckungsamtshilfegesetz, "SWI" 2012, no. 7.

Olszanowski J., Piątek W., The development of mutual assistance of EU Member States for the recovery of public claims, "Law Review” 2014, no. 2.

Parida S., Automatic Exchange of Information, [in] Exchange of Information for Tax Purposes, eds. O.Ch. Günther, N. Tüchler, Wien 2013.

Seer R., Die Vollstreckungsamtshilfe in Steuersachen nach der neu gefassten Beitreibungsrichtlinie 2010/24/EU, "IWB" 2011, no. 4.

\section{SUMMARY}

\section{The validity of the principle of mutual trust between the EU Member States in mutual assistance for the recovery of public claims}

The cooperation between the EU Member States for the recovery of public claims has been gradually strengthened through expanding the subjective scope to new categories of public claims, establishing forms of cooperation, most notably the possibility to recover claims arising in one state by authorities of another state, and establishing separate institutional frameworks of cooperation. The EU legislature placed great emphasis on the most transparent development of relationships between the EU Member States, and thus the validity of the principle of trust. The article analyses the current international cooperation in the recovery of public claims in view of the principle of mutual trust between the Member States that forms the basis for such cooperation. 
102 | Adam Mickiewicz University Law Review

Keywords: mutual assistance between EU Member States, principle of mutual trust, recovery of public claims

Jan Olszanowski, Adam Mickiewicz University Poznań, Faculty of Law and Administration, Al. Niepodległości 53, 61-714 Poznań, Republic of Poland, e-mail: jan.olszanowski@amu.edu.pl.

Wojciech Piątek, Adam Mickiewicz University Poznań, Faculty of Law and Administration, Al. Niepodległości 53, 61-714 Poznań, Republic of Poland, e-mail: wojciech. piatek@amu.edu.pl. 